\title{
FINITE ELEMENT MODELLING AND SIMULATION OF VEHICLE IMPACT ON STEEL SAFETY BARRIERS
}

\author{
Riassa LikHONinA*, MiCHAl MickA \\ Czech Technical University in Prague, Faculty of Transportation Sciences, Prague, Czech Republic \\ * corresponding author: likhorai@fd.cvut.cz
}

\begin{abstract}
This paper deals with a FEA simulation of the vehicle crash with steel safety barriers in the ANSYS LS-DYNA ${ }^{\circledR}$ 15.0. Two types of safety barriers are used: the JSNH4/H2 and the JSAM-2/H2. A geometrical model of the barrier in the Modeler ANSYS ${ }^{\circledR}$ Workbench $^{\mathrm{TM}} 15.0$ was created and then it was transformed into the LS-DYNA ${ }^{\circledR} 15.0$ to complete the crash test simulation. After a computation in the solver ANSYS LS-DYNA ${ }^{\circledR}$ 15.0, the results of the simulation such as impact forces, a body displacement and an integral energy were analyzed.
\end{abstract}

KEYWORDS: finite element method; crash simulation; ANSYS ${ }^{\circledR}$ Workbench $^{\text {TM }}$; LS-DYNA ${ }^{\circledR}$.

\section{INTRODUCTION}

Currently, all safety barriers for permanent and repeated use on the roads have to be tested in real crash tests. The methods and all corresponding specifications of preparations and the performance of crash tests and evaluation of the obtained results are specified in ČSN EN standards [9. A numerical simulation by finite element methods (FEM) is commonly and widely used in automotive industry [10. It can distinclty help, for example, to define deformation areas of cars and their safety elements, which would eliminate fatal injuries when accidents take place. According to relevant standards, each type of a safety barrier is required to be tested by several types of crash tests. Moreover, it should be considered that during real crash tests it is not possible to take all parameters and situations that could appear into account. It is well known that some deviations will always appear. Therefore, a FEA simulation with an application of highly sophisticated programs that use a FEM analysis can present a very powerful tool and be a great support for performing real crash tests, thus contributing to a correct and accurate design and construction of safety barriers.

Due to the advantages the FEA simulation can bring, the interest in this method is increasing. A large number of publications, which are really diverse as far as the subjects of investigation and main objectives are concerned, exists in this field. Some of the papers are devoted to the testing of new types of safety barriers, which are made of a new material and which are not used on real roads yet [15, 21. Other works describe simulation of impacts on bridge barriers or even on rockfall barriers [20. One of the earliest publications in this area was a work by Gruber K., Herrmann M. and Pitzer M., where, already in 1991, the authors described a computer simulation of a side impact. For these purposes they used different types of mobile barriers. Borovinšek $M$. in his work uses simulation for designing optimal reinforcement of a crash barrier commonly used in Slovenia 6]. Another example of an application of the FEA simulation is a publication by Ulker M. B. C. and Rahman M. S., "Traffic Barriers under Vehicular Impact from Computer Simulation to Design Guidelines", where the problem of a vehicular impact on a portable concrete barrier is investigated [19]. Borkowski W., Hryciów Z., Rybak P., Wysocki J. and Wisniewski A. use the FEA simulation to evaluate the effectiveness of the innovative road safety system prototype that has a body made of plastic filled with reinforced concrete. [5]. In another interesting work, which was written by Ing. J. Drozda and doc. Ing. T. Rotter, the numerical analysis of designing and testing of bridge barriers is discussed [11]. In his other work, "Methodology of Validation of FE Model for Simulations of Real Crash Tests", Drozda J. tries to determine a method that leads to a creation of a validated finite element model before performing the full scale crash test [10]. Similar investigations using FEA simulation are made all around the world: in Italy [4, in Korea [15], in China [14, in the USA [7, 8, in Romania [12] and so on. And the authors of such publications have come to a similar conclusion that FEA simulation is a very helpful tool for design and construction as well as for testing of crash barriers.

In the presented work, the FEM program ANSYS ${ }^{\circledR}$ Workbench $^{\mathrm{TM}}$ 15.0, LS-DYNA ${ }^{\circledR} 15.0$ and LS-PrePost ${ }^{\circledR} 4.1$ are used for the FEA simulation of the static and the dynamic tests of barriers .

\section{STEEL SAFETY BARRIERS}

The subject of the presented work is road restraint systems, or to be more precise - steel safety barriers. From a large number of different steel safety barriers, two types have been used for the analysis (both made by the same manufacturer): JSNH4/H2 and JSAM$2 / \mathrm{H} 2$. The latter is a new type, which claims to have several benefits comparing with JSNH4/H2. The goal of the simulation was to create a model of a safety bar- 
rier JSAM-2/H2 in ANSYS ${ }^{\circledR}$ Workbench $^{\text {TM }} 15.0$ and to set parameters of both models in LS-PrePost ${ }^{\circledR} 4.1$ : defining deformation curves and impact conditions (velocity, vehicle density, etc.), setting the material characteristics for separate parts of the crash barriers, modifying contacts between the corresponding parts, etc. This article shows the correlation of FEA results with the literature test data results [16].

In the Czech Republic, the crash barriers can only be used on the roads if they comply with the requirements specified in TP 114 [18. Compliance with these requirements is verified by crash tests according to ČSN EN 1317-2 99. On the basis of these crash tests, the final containment level is determined. For a majority of the containment levels, there should be two or more types of crash tests. This is valid for "approved" crash barriers. For "other" crash barriers, calculation is used. However, it is not common for several reasons. The most important of these reasons is the fact that calculations are not able to provide a sufficient basis for an assessment of the complex suitability of a certain crash barrier as a road restraint system and, thus, to forecast "impact acceptability", because "impact acceptability" is a combination of many factors. Another reason why calculations are not often used, is the lack of methodological guidelines, recommendations and documents dealing with this issue. However, for bridge crash barriers, the calculations are allowed; moreover they are, in accordance with corresponding standards, recommended [17]. On the other hand, the implementation and evaluation of crash tests, although it is strictly prescribed for some cases and situations, is expensive and demanding on the equipment of the laboratory. Moreover, the application of the results of the crash tests in prediction of how the barrier will behave in practice, i.e. on roads and during certain impacts, is contentious. Therefore, emphasizing advantages and disadvantages of both methods it could be shown that a FEA simulation can be a promising method for forcasting behavior of a crash barrier when collision happens [17]. The implementation and evaluation of crash tests, although it is strictly prescribed for some cases and situations, is expensive and demanding on the equipment of the laboratory. Moreover, the application of the results of the crash tests in prediction of how the barrier will behave in practice, i.e., on roads and during certain impacts, is contentious [17.

The calculations could be used as "means for making the preparation of a crash test" [17]. In comparison with the "trial and error", it will bring substantial savings. For example, with the help of calculations it is often possible to predict the influence of the change in the construction of the crash barriers (e.g., construction changes of connecting parts, changes of the element length, etc.) on their strength and stiffness, and then to select the appropriate parameters of crash tests. Moreover, the calculation results can be used to design and test new and completely innovative types of crash barriers. And this is where FEA simulation can play a significant role as it saves time and decreases expenses [17].

In the presented work, there is an attempt to simulate a vehicle impact on two crash barriers and to prove that FEA simulation, in this area, has great prospects.

\section{Finite ELEMENT MODELling AND SIMULATION}

This chapter describes the construction, parameters and installation of the selected types of safety barriers, i.e., JSNH4/H2 and JSAM-2/H2. The 3D models of the safety barriers JSNH4/H2 and JSAM-2/H2 have been created in the ANSYS ${ }^{\circledR}$ Workbench $^{\mathrm{TM}}$ 15.0. The numerical model was created for one field of the barrier due to size limitations of the task. A model of a safety barrier itself consists of a post, two parts of a spacer, barrier strips and lower beams. All parts of each of the geometrical models have exactly the same sizes as specified in the technical documents by the manufacturer. These elements are actually interconnected by bolts, nuts and washers specified in the technical documents by the manufacturer. However, in the numerical model, these connecting elements have been replaced with bonded face contacts. For the FEA simulation purpose, models of the ground and a vehicle are created. They will impact the safety barrier according to given consideration. In both cases, the ground is represented by rectangular blocks with cylinder concrete block as a ground of the column of the barrier. As for the vehicle, it is represented by a semi-cylinder [16]. It is located in such a way that its upper edge is on the level of the upper edge of the post and its height is sufficient enough to impact both the barrier strip and the lower beam. In this stage, the vehicle does not touch the crash barrier and is app. $20 \mathrm{~mm}$ far from it. The problem is solved as a symmetrical one, therefore, the symmetry is supposed in the place of the loading of the model. This fact explains why a semi-cylinder is used instead of a whole cylinder for the model of a vehicle. The impact area in case of symmetry is app. $0.25 \times 0.25 \mathrm{~m}$, which is in compliance with the standards, as mentioned in previous chapters. The last thing defined in the ANSYS ${ }^{\circledR}$ Workbench $^{\mathrm{TM}} 15.0$ were the boundary conditions. For both models, the displacement of the barrier strips and lower beams using symmetry conditions is defined. The displacement of the vehicle was specified so that only a movement, which has a perpendicular direction to the barrier strip, was allowed. A movement of the ground is not allowed in any other direction.

As it can be seen from Table 1, both types of the crash barriers have the same containment level, that is in terms with the crash test types performed for their validation and certification [1. However, they differ in used materials as JSAM-2/H2 is made of the new micro-alloyed steel, which, according to the manufacturer, allows a reduction of the overall weight, 


\begin{tabular}{|c|c|c|}
\hline & JSNH4/H2 & JSAM-2/H2 \\
\hline Manufacturer & $\begin{array}{l}\text { ArcelorMittal Distribution Solutions } \\
\text { Czech Republic, s.r.o. }\end{array}$ & $\begin{array}{c}\text { ArcelorMittal Distribution Solutions } \\
\text { Czech Republic, s.r.o. }\end{array}$ \\
\hline Type & Single-sided safety barrier & Single-sided safety barrier \\
\hline Containment level & $\mathrm{H} 2$ & $\mathrm{H} 2$ \\
\hline Dynamic deflection & $1.75 \mathrm{~m}$ & $1.5 \mathrm{~m}$ \\
\hline Working width & $1.85 \mathrm{~m}$ & $1.6 \mathrm{~m}$ \\
\hline Acceleration severity index & 1.186 & 1.1 \\
\hline Material & S235JR, S355MC & S235JR, S355MC, S420MC \\
\hline Type of a barrier strip & $\begin{array}{l}\text { NH4: thickness } 4 \mathrm{~mm} \text {, length } \\
4250 \mathrm{~mm}\end{array}$ & $\begin{array}{l}\text { AM: thickness } 2.8 \mathrm{~mm} \text {, length } \\
4250 \mathrm{~mm}\end{array}$ \\
\hline Lower beam & $\begin{array}{l}\text { SP3: thickness } 3 \mathrm{~mm} \text {, height } \\
214 \mathrm{~mm} \text {, width } 28 \mathrm{~mm} \text {, length } \\
4250 \mathrm{~mm}\end{array}$ & $\begin{array}{l}\text { AM: thickness } 2.8 \mathrm{~mm} \text {, height } \\
214 \mathrm{~mm} \text {, width } 28 \mathrm{~mm} \text {, length } \\
4250 \mathrm{~mm}\end{array}$ \\
\hline Post & $\begin{array}{l}\text { V140: thickness of a wall } 5 \mathrm{~mm} \text {, } \\
\text { width } 140 \mathrm{~mm} \text {, length } 2170 \mathrm{~mm}\end{array}$ & $\begin{array}{c}\text { C } 150 \times 75 \times 25: \text { thickness of a wall } \\
3.5 \mathrm{~mm} \text {, width } 150 \mathrm{~mm} \text {, length } \\
1755 \mathrm{~mm}\end{array}$ \\
\hline Weight & $42.67 \mathrm{~kg} / \mathrm{m}$ & $29 \mathrm{~kg} / \mathrm{m}$ \\
\hline
\end{tabular}

TABLE 1. Comparison of JSNH4/H2 and JSAM-2/H2 [16.

while preserving the same or even better functionality. As Table 1 shows, the application of the new steel type enables production of these parts of the safety barrier JSAM-2/H2 with a smaller thickness. Besides, the post has been changed both in terms of cross section and its dimensions. All of this affects important parameters like the dynamic deflection, the working width and the acceleration severity index. This fundamentally improves the characteristics of the safety barrier. But the main achievement is the weight reduction that is approximately $32 \%$ - from $42.67 \mathrm{~kg} / \mathrm{m}$ to $29 \mathrm{~kg} / \mathrm{m}$.

This fact is not only beneficial in terms of costs, but also in terms of influence on the environment. Also, the maintenance and installation is much easier. In simulation, the following materials were used: S235JR for JSNH4/H2 and S355J0 for JSAM-2/H2. Their load curves used in the ANSYS ${ }^{\circledR} 15.0$ are shown in Figure 1. The vehicle is modeled by a cylinder, whose material is isotropic elastic (see Table 2). For the ground, the material of the type GEOLOGIC_CAP_MODEL was used. The parameters listed in Table 3 were specified for this material. For concrete, the standard model CSCM_CONCRETE with default parameters was used.

Notice that the value of the mass density of the "vehicle" differs according to what type of a crash test has to be simulated. The mass density is calculated from the weight of the car and the dimensions of the car model according to the following formula:

$$
\varrho=\frac{m}{V} \quad \text { and } \quad V=\frac{\pi r^{2} h}{2},
$$

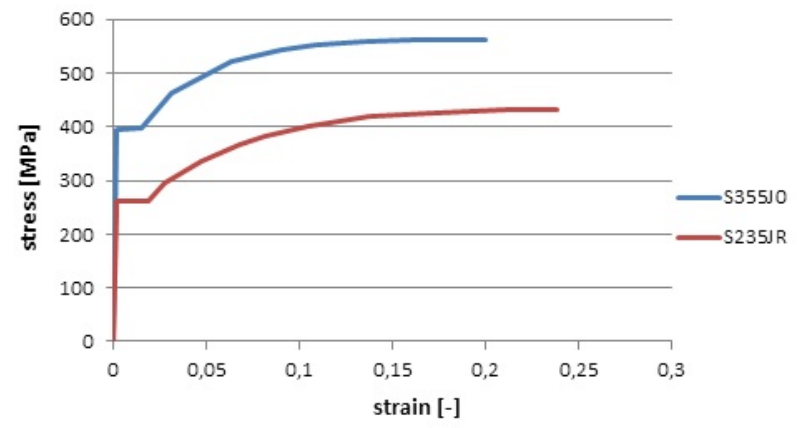

FIGURE 1. Comparison of the working curve of S235JR and S355J0 steel used in simulation [16.

\begin{tabular}{lc}
\hline Mass density $\left[\mathrm{kg} / \mathrm{m}^{3}\right]$ & \\
— passenger car & $2.621 \cdot 10^{4}$ \\
— lorry & $2.912 \cdot 10^{5}$ \\
— bus & $3.785 \cdot 10^{5}$ \\
\hline Young's Modulus $[\mathrm{Pa}]$ & $2.000 \cdot 10^{11}$ \\
\hline Poisson's ratio $[-]$ & 0.3 \\
\hline
\end{tabular}

TABle 2. Parameters for specification of vehicle material type [16].

where $\varrho$ is a mass density $\left[\mathrm{kg} / \mathrm{m}^{3}\right], m$ is a car mass $[\mathrm{kg}], V$ is a volume $\left[\mathrm{m}^{3}\right], r=0.150 \mathrm{~m}$ is a radius of a cylinder and $h=0.7 \mathrm{~m}$ is a height of a cylinder. The same meshing properties are specified for both models. The element size is $0.20 \mathrm{~m}$, the minimum edge length is $3 \cdot 10^{-3} \mathrm{~m}$; the smoothing, the relevance center and the span angle center are set to be medium. 


\begin{tabular}{lcc}
\hline Name & Description & Value \\
\hline RO $\left[\mathrm{kg} / \mathrm{m}^{3}\right]$ & Mass density & 2100 \\
\hline BULK $[\mathrm{Pa}]$ & Initial bulk modulus & $4.102 \cdot 10^{7}$ \\
G $[\mathrm{Pa}]$ & Initial shear modulus & $3.076 \cdot 10^{7}$ \\
\hline ALPHA & Failure envelope parameter & 2 \\
THETA & Failure envelope linear coefficient & 0.292 \\
GAMMA & Failure envelope exponential coefficient & 0 \\
BETA & Failure envelope exponent & 0 \\
\hline R & Cap, surface axis ratio & 3 \\
\hline D $[\mathrm{Pa}]$ & Hardening law exponent & $7.524 \cdot 10^{7}$ \\
W $[\mathrm{Pa}]$ & Hardening law coefficient & 0.031394 \\
X0 $[\mathrm{Pa}]$ & Hardening law exponent & 0 \\
\hline C & Kinematic hardening coefficient & 1 \\
N & Kinematic hardening parameter & 1 \\
\hline FTYPE & Formulation flag & 1 - default - means soil \\
VEC & Vectorization flag & $0-$ default - means vectorized \\
\hline
\end{tabular}

TABLE 3. Parameters for ground specification [16.

\section{Results And Discussion}

The numerical model was transformed from the ANSYS $^{\circledR}$ Workbench ${ }^{\mathrm{TM}} 15.0$ to the ANSYS LSDYNA ${ }^{\circledR} 15.0$ and solved. The results were evaluated in the program LS-PrePost ${ }^{\circledR} 4.1$.

The next figures show the most important results from the FEA simulation of the crash test TB11 performed for the JSAM-2/H2. From a graph of the vehicle kinetic energy (see Figure 2), it can be seen that its value is gradually decreasing within the impact and in the end it reaches $1.7735 \mathrm{kNm}$. Its maximum value, at the beginning of the impact, is $18.288 \mathrm{kNm}$, which means $36.576 \mathrm{kNm}$ for a symmetrical task.

The vehicle velocity decreases as well and reaches almost zero (see Figure 3). Its initial value of $9.5006 \mathrm{~m} / \mathrm{s}$ is set before simulation and corresponds to the crash speed value specified in standards [9].

The following figures illustrate safety barrier deformation at a time step of $0.125 \mathrm{~s}$ (see Figure 4 ).

The most interesting and informative is the graph showing the internal energy of the construction (see Figure 5.

It can be seen that the maximum value is $57.611 \mathrm{kNm}$, i.e., $115.222 \mathrm{kNm}$ for a symmetrical task. When we look at the internal energy at a time step of $0.125 \mathrm{~s}$, as we did for the JSNH4/H2, its value is equal to $44 \mathrm{kNm}$, i.e., $88 \mathrm{kNm}$ for a symmetrical task. These values more than fully comply with the value specified in the TP $114(40.600 \mathrm{kNm})$ and with the value of the kinetic energy obtained during the simulation $(36.576 \mathrm{kNm})$. Therefore, it can be stated that the FEA simulation of the crash test TB11 for the JSAM2/H2 was successfully performed according to both the criteria of consumed energy and the maximum displacement value at a certain time step.

The next graph of interest is the one that illus-

\begin{tabular}{lcc}
\hline Crash test & \multicolumn{2}{c}{ Impact force $[\mathrm{kN}]$} \\
\cline { 2 - 3 } & JSNH4/H2 & JSAM-2/H2 \\
\hline TB11 & $74.250-105.183$ & $38.250-82.840$ \\
\hline TB42 & $130-183.440$ & $45-157.560$ \\
\hline TB51 & $104-218.978$ & $78-211.380$ \\
\hline
\end{tabular}

TABLE 4. Comparison of JSNH4/H2 and JSAM-2/H2 - impact forces [16.

trates the acceleration of the vehicle (see Figure 6). It can be seen that the maximum value of the acceleration reaches $92.044 \mathrm{~m} / \mathrm{s}^{2}$. At a time step of $0.125 \mathrm{~s}$, it is equal to $42.500 \mathrm{~m} / \mathrm{s}^{2}$. Therefore, the impact forces corresponding to these values of acceleration are $82.8396 \mathrm{kN}$ and $38.250 \mathrm{kN}$, respectively. Mind the fact that the TP 101 specifies the following alternative load forces corresponding to the crash test TB11: 15$35 \mathrm{kN}$ for a crash barrier with a dynamic deflection of $1.500-2.500 \mathrm{~m}$ and $35-80 \mathrm{kN}$ for a crash barrier with a dynamic deflection of $0.100-0.500 \mathrm{~m}$ [17]. It can be seen that the impact forces obtained during the FEA simulation are sufficient, or even higher, than the alternative load forces described in the TP 101 [17].

\subsection{COMPARISION OF FEA RESUlts FOR JSNH4/H2 AND JSAM-2/H2}

Comparing the two types of the crash barriers it can be noticed that the impact forces, which the safety barrier can resist, are higher for JSNH4/H2 for all of the crash tests (see Table 4 ).

It is explained by the fact that JSNH4/H2 has a higher stiffness due to the construction dimensions. There is also a difference in the values of the internal energy of the two types, which is presented in the 


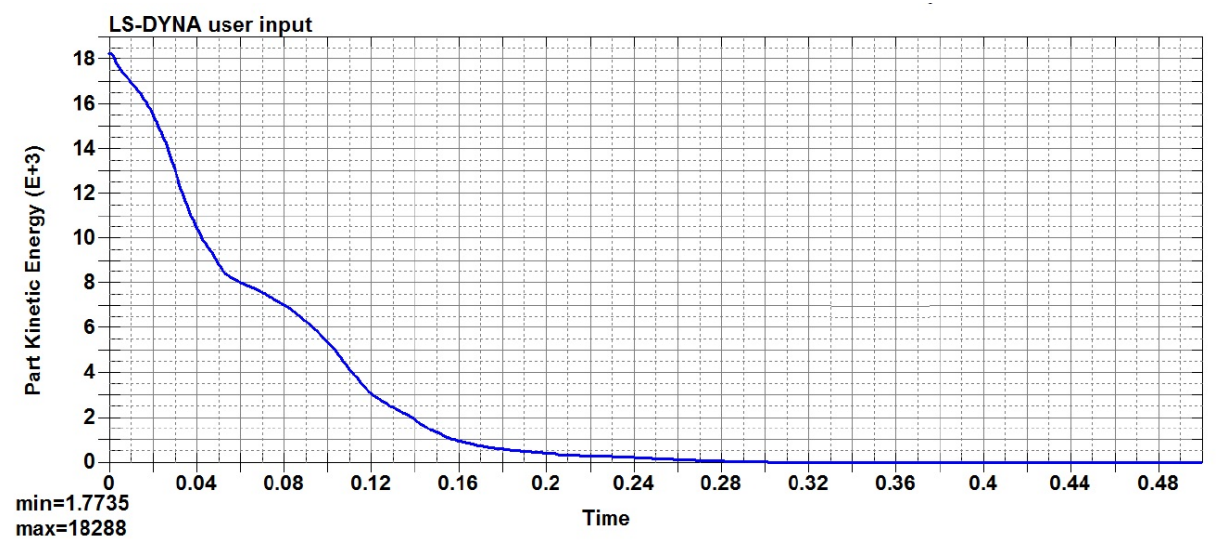

Figure 2. Kinetic energy of a vehicle - JSAM-2/H2, TB11 [16.

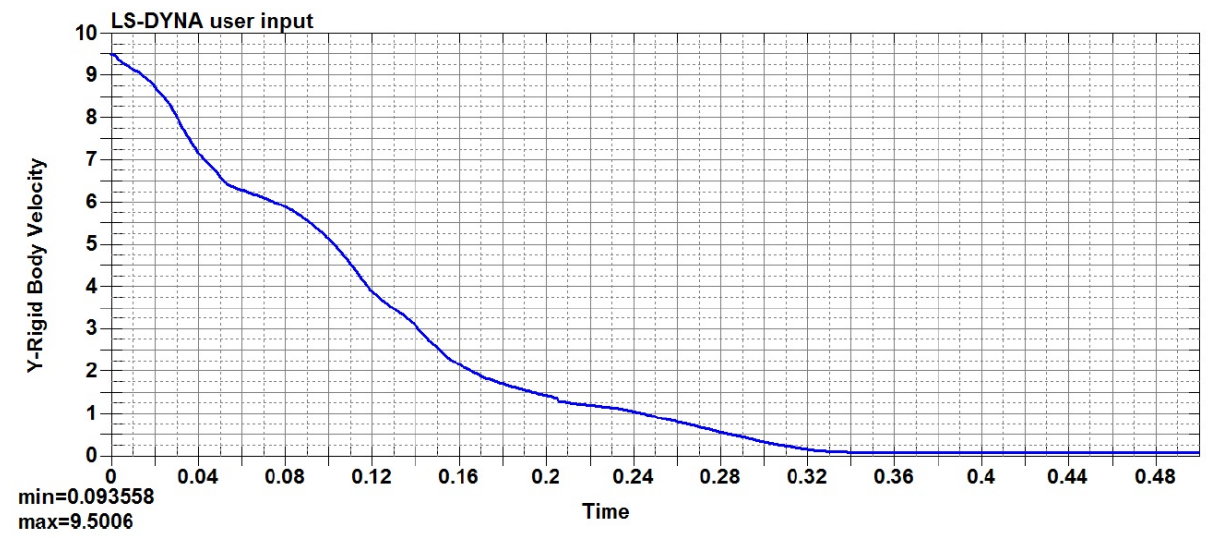

Figure 3. Vehicle velocity — JSAM-2/H2, TB11 [16].
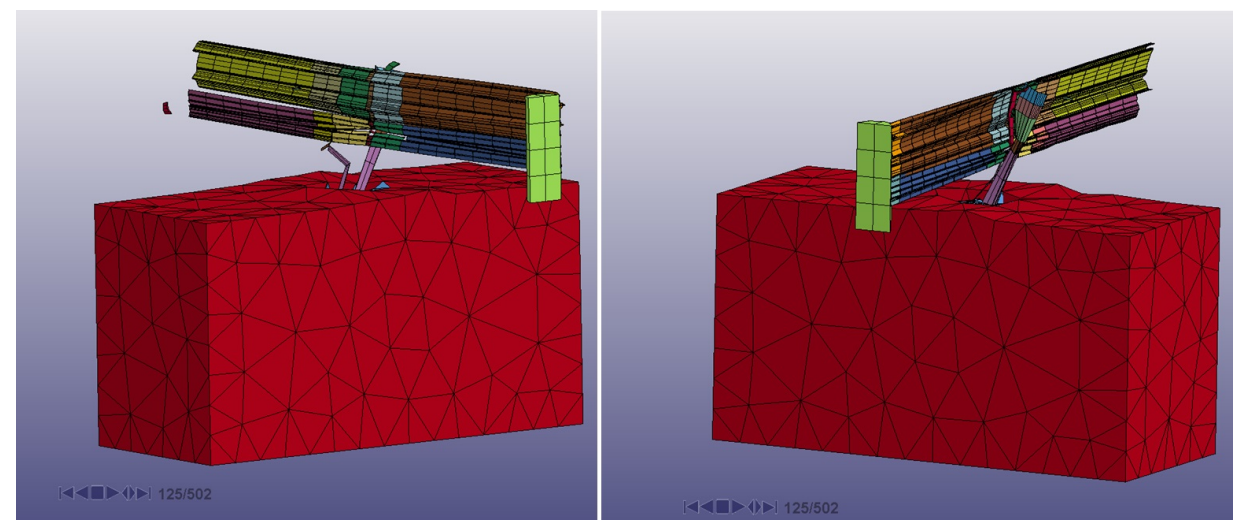

FiguRE 4. Safety barrier deformation at time step $0.125 \mathrm{~s}-$ JSAM-2/H2, TB11 [16.

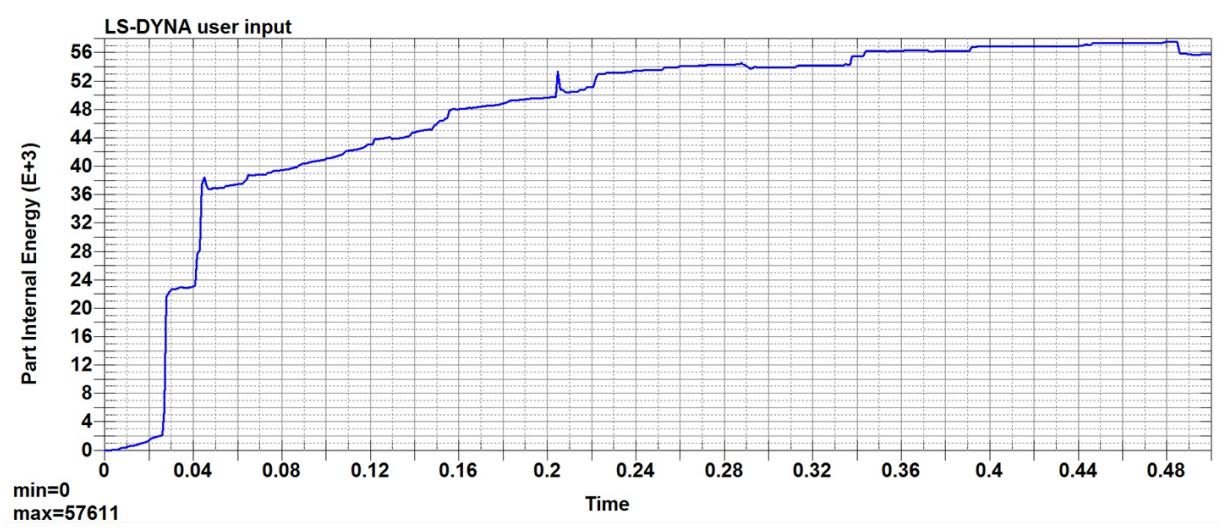

FiguRE 5. Internal energy — JSAM-2/H2, TB11 [16]. 


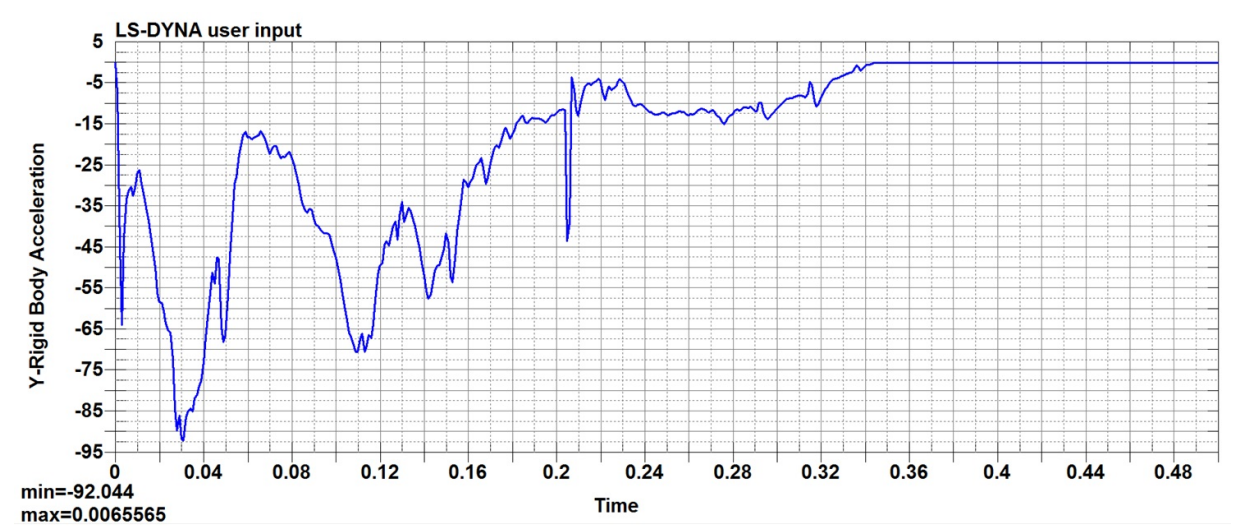

Figure 6. Vehicle acceleration — JSAM-2/H2, TB11 [16].

\begin{tabular}{lcc}
\hline Crash test & \multicolumn{2}{c}{ Internal energy $[\mathrm{kNm}]$} \\
\cline { 2 - 3 } & JSNH4/H2 & JSAM-2/H2 \\
\hline TB11 & 43 & 88 \\
\hline TB42 & 135 & 120 \\
\hline TB51 & max. 233.760 & max. 245.050 \\
\hline
\end{tabular}

TABLE 5. Comparison of JSNH4/H2 and JSAM-2/H2 — internal energy [16].

following table (see Table 5 .

The value of the internal energy in TB11 for JSAM$2 / \mathrm{H} 2$ is approximately twice higher than that for the JSNH4/H2. From this, it can be concluded that the JSAM-2/H2 better absorbs kinetic energy of a vehicle during an impact, and therefore it is safer for passengers. This fact is also proved by the ASI index specified in the technical documentation, which is lower for the JSAM-2/H2: 1.1 as compared with 1.186 [2, 3]. Similarly, the value of the internal energy obtained during the TB51 is higher for the JSAM-2/H2 in comparison with the JSNH4/H2. However, it is a little bit lower during the TB42.

\subsection{Correlation of Results}

Table 6 represents the values of the kinetic energy obtained during real crash tests and an alternative load force used during the calculations for crash test types TB11, TB42 and TB51. These values are specified in the technical standards $[9,17$.

According to the results, which were obtained during the FEA simulation and discussed in previous section, it can be concluded that both safety barriers passed the crash tests TB11 and TB42 according to the criteria of the consumed energy, and therefore the models correspond to the containment level H1. According to the impact forces the barriers are able to withstand, both types passed all three crash tests TB11, TB42, TB51 - and, thus, correspond to the containment level $\mathrm{H} 2$ specified in the technical documents by the manufacturer $[2,3$.

Taking into consideration the mentioned facts, it can clearly be seen that by the performance of the same functions, the crash barrier JSAM-2/H2 proved to have several advantages against the crash barrier JSNH4/H2. Among them is a better energy absorption, and therefore higher safety for the vehicle occupants. Another advantage is its weight, which is lower by $32 \%$ than the weight of the 2JSNH4/H2 $(29 \mathrm{~kg}$ against $42.670 \mathrm{~kg}$ ) [2, 3].

\section{Conclusions}

Resuming all the facts, it can be concluded that the ANSYS $^{\circledR}{ }^{\text {Workbench }}{ }^{\mathrm{TM}} 15.0$ and the ANSYS LSDYNA ${ }^{\circledR} 15.0$ proved to be very good tools for a stress assessment of different constructions - resistance against plastic deformation. Though it is indicated in standards that the safety barriers should be tested in real crash tests, preparation and financing of such tests is, however, a challenging task. The ANSYS ${ }^{\circledR}$ has excellent tools for simulating similar tests and it can be used for preliminary calculations, which would help to avoid possible mistakes and wasting time. Besides, it would reduce costs, and what is most important - increase the efficiency of the preparation of experimental tests and improve the final results.

\section{REFERENCES}

[1] ArcelorMittal Europe, 2014. Flat Products. Update. Zákaznický časopis: May 2014. Retrieved from: http://flateurope.arcelormittal.com/ repository2/About/CZ_Update_May14.pdf

[2] ArcelorMittal Ostrava a.s. Jednostranné svodidlo JSNH4/H2. Retrieved from: http://www.kaska.eu/uploads/2012_JSNH4-H2.pdf

[3] ArcelorMittal Ostrava a.s. Jednostranné svodidlo JSAM-2/H2. Retrieved from: http://www.doznac.cz/ wp-content/uploads/6_JSAM-2-H2.pdf

[4] Bonin G., Cantisani G., Loprencipe G.. Computational 3D models of vehicle's crash on road safety systems. Universita di Roma "La Sapienza", Rome, Italy.

[5] Borkowski W., Hryciów Z., Rybak P., Wysocki J., Wiśniewski A.. Studies on the effectiveness of the innovative road safety system. Journal of KONES Powertrain an Transport, Vol. 21, No. 2, 2014. 


\begin{tabular}{ccccc}
\hline Test & $\begin{array}{c}\text { Alternative load } \\
\text { force barriers } \\
\text { specified in [17 }\end{array}$ & $\begin{array}{c}\text { Impact force obtained } \\
\text { in simulation: } \\
\text { JSNH4 (top value), } \\
\text { JSAM-2 (bottom value) }\end{array}$ & $\begin{array}{c}\text { Kinetic energy } \\
\text { specified in [9] }\end{array}$ & $\begin{array}{c}\text { Internal energy obtained } \\
\text { in simulation: } \\
\text { JSNH4 (top value), } \\
\text { JSAM-2 (bottom value) }\end{array}$ \\
\hline TB11 & $15-35 \mathrm{kN}$ & $74.3-105.2 \mathrm{kN}$ & $40.6 \mathrm{kNm}$ & $43 \mathrm{kNm}$ \\
& & $38.3-82.8 \mathrm{kN}$ & $126.6 \mathrm{kNm}$ & $88 \mathrm{kNm}$ \\
\hline TB42 & $45-80 \mathrm{kN}$ & $130-183.4 \mathrm{kN}$ & $135 \mathrm{kNm}$ \\
& & $45-157.6 \mathrm{kN}$ & $287.5 \mathrm{kNm}$ & $120 \mathrm{kNm}$ \\
\hline TB51 & $90-140 \mathrm{kN}$ & $104-219 \mathrm{kN}$ & $233.8 \mathrm{kNm}$ \\
& & $78-211.4 \mathrm{kN}$ & & $245.1 \mathrm{kNm}$ \\
\hline
\end{tabular}

TABLE 6. Correlation of FEA results.

[6] Borovinšek M., Vesenjak M., Ulbin M., Ren Z. Simulating the impact of a truck on a road-safety barrier. Strojniški vestnik: Journal of Mechanical Engineering 52(2006)2.

[7] Consolazio G. R., Chung H. J., Gurley K. R. Impact simulation and full scale crash testing of a low profile concrete work zone barrier. Departement of civil and coastal engineering. University of Florida: USA, 2002.

[8] Consolazio G. R., Chung J. H. Vehicle impact simulation for curb and barrier design. Volumi I Impact simulation procedures. Center for advanced infrastructure \& transportation, Civil \& Environmental engineering: Rutgers, The state university, Piscataway, NJ 08854-8014, October 1998

[9] ČSN EN 1317-2 Silniční záchytné systémy. Č́st 2: Svodidla a mostní svodidla. Funkční třídy, kritéria přijatelnosti nárazových zkoušek a zkušební metody. ICS 13.200; 93.080.30, Únor, 2011.

[10] Drozda J., 2014. Methodology of validation of FE Model for simulations of real crash tests. In. Sborník semináře doktorandů katedry ocelových a dřevěných konstrukcí: Praha, March 3 and October 10, 2014. Katedra ocelových a dřevěných konstrukcí FSv ČVUT. Nadace Františka Faltuse. pp. 43-48. ISBN 978-80-0105522-9. Retrieved from: http://www.ocel-drevo.fsv cvut.cz/NFF/docs/sborniky/NFF-sbornik14.pdf

[11] Drozda J., Rotter R. Využití numerické analýzy pro návrh a ověření mostních svodidel. Centre for Effective and Sustainable Transport Infrastructure, WP3, 3.8b, 2014. Retrieved from: http://www.cesti.cz/ technicke_listy/t12014/2014_WP3_TL3_8b.pdf

[12] Dumitrache P. Numerical simulation of the behaviour of the safety barriers and experimental validation. Dunarea de Jos University Galaji, Engineering faculty Braila: Romania, 2010. Retrieved from: http: //das.tuwien.ac.at/fileadmin/mediapool-das/ Diverse/Publications/BoA_Siofok/files/p047.pdf
[13] Gruber K., Herrmann M., Pitzer M. Computer simulation of side impact using different mobile barriers. DOI 10.4271/910323. 1991. Retrieved from: http://papers.sae.org/910323/

[14] Hao H., Deeks J. A., Wu C.. Numerical Simulations of the performance of steel guardrails under vehicle impact. Transactions of Tianjin University: October 2008.

[15] Hong K.-E., Thai H.-T., Kim S.-E. Numerical simulation of composite safety barrier under vehicle impact. Dept. of Civil \& Environmental Engineering, Sejong University: Korea, 2010.

[16] Likhonina R., 2015. Numerical simulation of impact with barriers (master's thesis). FD ČVUT, Praha, 2015. $162 \mathrm{p}$.

[17] TP 101 Výpočet svodidel. Č.j. 26514/97-120. Praha: Ministerstvo dopravy a spojů, Odbor pozemních komunikací, Dopravoprojekt, 1998.

[18] TP 114. Svodidla na pozemních komunikačních: Zatížení. Stanovení úrovně zadržení na PK. Navrhování „jiných" svodidel. Zkoušení a uvádění svodidel na trh. Č.j. 148/10-910-IPK/1. Praha: Ministerstvo dopravy, Odbor silniční infrastruktury, Dopravoprojekt Brno, a.s., 2010.

[19] Ulker M. B. C., Rahman M. S. Traffic barriers under vehicular impact from computer simulation to design guidelines. Comp.-Aided Civil and Infrastructure Engineering 23(6): 2008.

[20] Wu C., Hao H., Deeks J. A. Vehicle impact response analysis of two-rail steel RHS traffic barrier. Taylor and Francis Group: ISBN 905809659 9, London, 2005.

[21] Zike S., Kalkins K., Ozolins O. Experimental verification of simulation model of impact response tests for unsaturated polyester/GF and PP/GF composites. CMMS Journal: 2011. Retrieved from: http: //www.cmms.agh.edu.pl/abstract.php?p_id=317 